\title{
Reducing the acidity of Arabica coffee beans by ohmic fermentation technology
}

\author{
${ }^{1,2 *}$ Reta, ${ }^{3}$ Mursalim, ${ }^{3}$ Salengke, ${ }^{3}$ Junaedi, M., ${ }^{3}$ Mariati. and ${ }^{4}$ Sopade, P. \\ ${ }^{1}$ Graduate School, Hasanuddin University, Makassar 90245 Indonesia \\ ${ }^{2}$ Department of Plantation Crop, Agriculture Polytechnic Pangkep, Pangkep 90655 Indonesia \\ ${ }^{3}$ Department of Agriculture Technology Faculty of Agriculture, Hasanuddin University, Makassar 90245 \\ Indonesia. \\ ${ }^{4}$ Center for Nutrition and Food Sciences, The University of Queensland, St Lucia QLD 4072, Australia
}

\section{Article history: \\ Received: 3 June 2017 \\ Received in revised form: \\ 29 June 2017 \\ Accepted: 30 June 2017 \\ Available Online: 2 July \\ 2017}

Keywords:

Ohmic technology,

Fermentation,

Coffee quality,

Arabica coffee

DOI:

http://doi.org/10.26656/

fr.2017.5.062

\begin{abstract}
Coffee is widely consumed not only because of its typical taste, but coffee has antioxidant properties because of its polygons, and it stimulates brain performance. The main problem with the consumption of coffee is its content of caffeine. Caffeine when consumed in excess, can increase muscle tension, stimulate the heart, and increase the secretion of gastric acid. In this research, we applied ohmic fermentation technology, which is specially designed to mimic the stomach. Arabica coffee has high acidity that needs to be reduced than Luwak coffee, although it is cheaper. Hence, the ohmic technology with a time and temperature variation were applied to measure the total acidity of the coffee to determine optimum fermentation conditions. Results revealed that the total acidity of the coffee varied with fermentation conditions $(0.18 \%-0.73 \%)$. Generally, the longer the fermentation and the higher the temperature, the lower the total acidity. The acidity of the Luwak coffee through natural fermentation was $2.34 \%$, which is substantially higher than the total acidity from the ohmic samples. Ohmic-based fermentation technology, therefore, offers improvements in coffee quality.
\end{abstract}

\section{Introduction}

Indonesia is the world's third-largest coffee producer after Brazil and Vietnam, with a production of about 700,000 metric tons in 2013, making up about $8 \%$ of the world's production (FAO, 2015). However, International Coffee Organization (ICO, 2015) reported the 2014/15 coffee production worldwide as 8.5 million metric tons, with about 600,000 produced in Indonesia, which was behind Brazil's, Vietnam's and Colombia's productions. During the same period, Indonesia exported about $60 \%$ of its total coffee production, while the rest (33\%) was for domestic consumption (ICO, 2015). From the estimates, the level of domestic coffee consumption per capital in Indonesia has risen from $500 \mathrm{~g}$ in 1989 to $1 \mathrm{~kg}$ in 2015 (Puslitkoka Indonesia, 2011; ICO, 2015). This is expected to keep rising as the benefits of coffee are wellknown, and its quality improves through novel processing techniques, such as ohmic technology.

Coffee is a prominent export commodity in
Indonesia and ranks third after rubber and pepper. South Sumatra is the topmost coffee producing region in Indonesia (ICO, 2011). South Sulawesi, in Eastern Indonesia, is another province in Indonesia with great potentials for development of coffee.The province has an extensive growing area and a conducive climate for coffee production, particularly Robusta and Arabica, and it has increased dramatically (Alam, 2006). Arabica coffee is mainly produced around Fort Malakaji Gowa with an altitude of $1,400 \mathrm{~m}$ above sea level. It is claimed that the Arabica coffee from this area has an excellent flavor (Wirabuana et al., 2003), but production is mainly through traditional steps, which needs to be upgraded to be competitive.

Coffee is important for its typical flavor and phytochemicals with antioxidant properties (Mulato, 2001). Coffee stimulates brain performance, and it is well known for its caffeine, which can increase muscle tension, stimulate the heart, and increase secretion of gastric acid (Mulato, 2001). Caffeine contents of coffee 
vary with types and processing, and values from 1.50 2.72\% have been reported for Robusta, while in Arabica, a range of $0.94-1.59 \%$ has been measured (Mulato, 2001). Development and retention of good taste or flavor in coffee is complex but mainly depend on post-harvest and processing issues. Puslitkoka Indonesia (2011) also reported on the importance of agro-climatic factors (soil conditions, altitude and cultivation techniques). Coffee produced in Indonesia is termed "coffee arbitrary", as it is generally of low quality with more than 225 defects identified (Misnawi and Sulistyowati, 2006). Such defects include strong odour, due to poor or inefficient fermentation (Ismayadi, 1998). Improper fermentation manifests in poor flavor, and this can be improved through an in-depth understanding of coffee fermentation requirements, and how fermentation conditions influenced coffee taste or flavor, with a view to optimizing the conditions for quality coffee. The coffee flavor has influenced the way of processing, especially the process of fermentation and roasting (Avallone et al., 2002; Jackels and Jackels 2005; Pimenta et al., 2009; Budryn et al., 2011; Wang, 2012). Fermentation is a chemical event that is useful in forming the precursor flavor of the coffee beans in the form of organic acids, amino acids and reducing sugars (Avallone et al., 2002; Bytof et al., 2005; Jackels and Jackels., 2005; Redgwel and Fischer, 2006; Chang Lin, 2010). Differences in the coffee processing will produce different flavors, mainly due to different chemical composition (Farah et al., 2006; Bytof et, al., 2005; Taba, 2012).

The objectives of the study, therefore, were to investigate the applicability of ohmic fermentation technology in coffee processing and to examine how acidity produced during coffee fermentation depended on time and temperature of ohmic processing.

\section{Materials and methods}

\subsection{Materials}

Fully ripe (red) Arabica coffee fruit was obtained from local farmers in Malakaji, Indonesia. Any foreign objects were sorted out. Then, the flesh, the fruit skin, and the pulp were removed to obtain the coffee seeds.

The coffee was fermented in an Ohmic reactor (Taba, 2012) at temperatures 30,35 and $40^{\circ} \mathrm{C}$, and for 2 18 hours. These fermentation conditions were selected based on the preliminary results (unpublished data) obtained from our laboratory. After fermentation, the coffee was washed before soaking for $10-12$ hours to remove the products of fermentation that could damage the quality of the coffee. The coffee was again washed before sun or oven-drying to reduce the moisture content to $12-13 \%$. The oven drying was done at $70^{\circ} \mathrm{C}$ at $40 \%$ humidity. The oven-drying of $50 \mathrm{~kg}$ coffee took between $12-18$ hours to complete.

\subsection{Determination of total acidity}

The total acidity of the coffee was determined following the procedure stated in AOAC (1995). Coffee samples were ground for 2 minutes. About $10 \mathrm{~g}$ of the ground coffee was weighed into an Erlenmeyer test tube, $75 \mathrm{~mL}$ of $80 \%$ alcohol was added, stopped and allow to stand for 16 hours with occasional shaking. The suspension was then filtered, and $25 \mathrm{~mL}$ of the filtrate was pipette into a beaker, diluted to $100 \mathrm{~mL}$ with deionised water and titrated with $0.1 \mathrm{~N} \mathrm{NaOH}$, using phenolphthalein. The total acidity was expressed as $\mathrm{mL}$ of $0.1 \mathrm{~N} \mathrm{NaOH}$ required for neutralization. Triplicate analysis was conducted.

\subsection{Statistical analysis}

Being preliminary, the data obtained was not subjected to any rigorous statistical analysis. Results are, therefore, discussed as indicative trends only.

\section{Results and discussion}

Figure 1 shows how the ohmic fermentation conditions nominally affected the moisture and total acidity of the Arabica coffee beans at different fermentation temperatures. The trends with the fermentation time appeared to be temperature dependent because both the total acidity and moisture would reduce along with the fermentation time at $30^{\circ} \mathrm{C}$ fermentation temperature but, at $40^{\circ} \mathrm{C}$, both acidity and moisture increased. Generally, relying on the main effects of fermentation time (Figure 1), the longer the time, the lower the total acidity, but the moisture content displayed an unexpected opposite trend above $35^{\circ} \mathrm{C}$. The acidity-time trend was expected because as the organism -substrate contact time increased, the fermentation was enhanced leading to the breakdown of coffee components that leached into the water with a corresponding decrease in the acidity of the coffee. According to Pimenta et al. (2009) and Jayus et al. (2011), fermentation helps to release mucus and soluble into fermentation media. The longer the fermentation, the lower is the pectin content of coffee as fermentation organisms degrade coffee pectin to acid compounds. Fermented coffee is relatively easy to wash, and it dries faster. 
Based on the analysis of water content in the treatment ohmic-based fermentation technology, the water content was in accordance with National Standard Indonesia No. 2907-2008 in the amount of 13.5\%, where the results obtained in the analysis of the water content of $10.79 \%$ is the lowest and the highest was $12.55 \%$. Coffee beans and water standards skinned horn is from $10 \%$ to $12 \%$. But, the treatment of 2 hours fermented coffee beans with a temperature of $35^{\circ} \mathrm{C}$ obtained a moisture content that does not comply with SNI is 20:59

On the temperature trends, the organisms responsible for biochemical changes during fermentation have their optimum temperatures, and the temperature dependence of the measured coffee properties could be due to this. As expected, Figure 1 reveals a possible inverse relationship between the fermentation temperature and the acidity (and moisture) of the coffee as temperature increases.

In Figure 1, it is shown that ohmic fermentation technology specifically reduced the total acidity at different temperatures and times of fermentation. The lowest acidity $(0.18 \%)$ was obtained at $30^{\circ} \mathrm{C}$ and 18 hours of fermentation while the highest acidity $(0.73 \%)$ was obtained at $30^{\circ} \mathrm{C}$ and 6 hours which could indicate an outlier. The highest acidity $(0.45 \%)$ was most likely to be at $40^{\circ} \mathrm{C}$ and 18 hours fermentation. This is, however, surprising and against the expected trends. The widest range of the coffee moisture content (10.2 $12.0 \%)$ at $35^{\circ} \mathrm{C}$.

Based on the analysis, the quality of Arabica coffee with the total acidity by fermentation time and temperature difference are significantly different to the criteria of quality Arabica coffee beans with ohmicbased fermentation (Budryn et al., 2011).

By comparing the average total acidity of Arabica coffee of the present study (ohmic technology) with previous studies (Laode et al., 2006; Wang, 2012) from the same location (Malakaji), it can be inferred that the ohmic technology produced better coffee fermentation on the basis of lower acidity obtained in the present study. Moreover, Bytof et al. (2005) and Hanifah and Desy (2013) reported the total acidity of civet stomachfermented coffee was $2.34 \%$ and naturally fermented was $1.87 \%$ (Laode et al., 2006), both were much higher values than the highest acidity value $(0.73 \%$ or $0.45 \%)$ obtained in the present study. This showed the advantages of the ohmic technology for coffee processing.
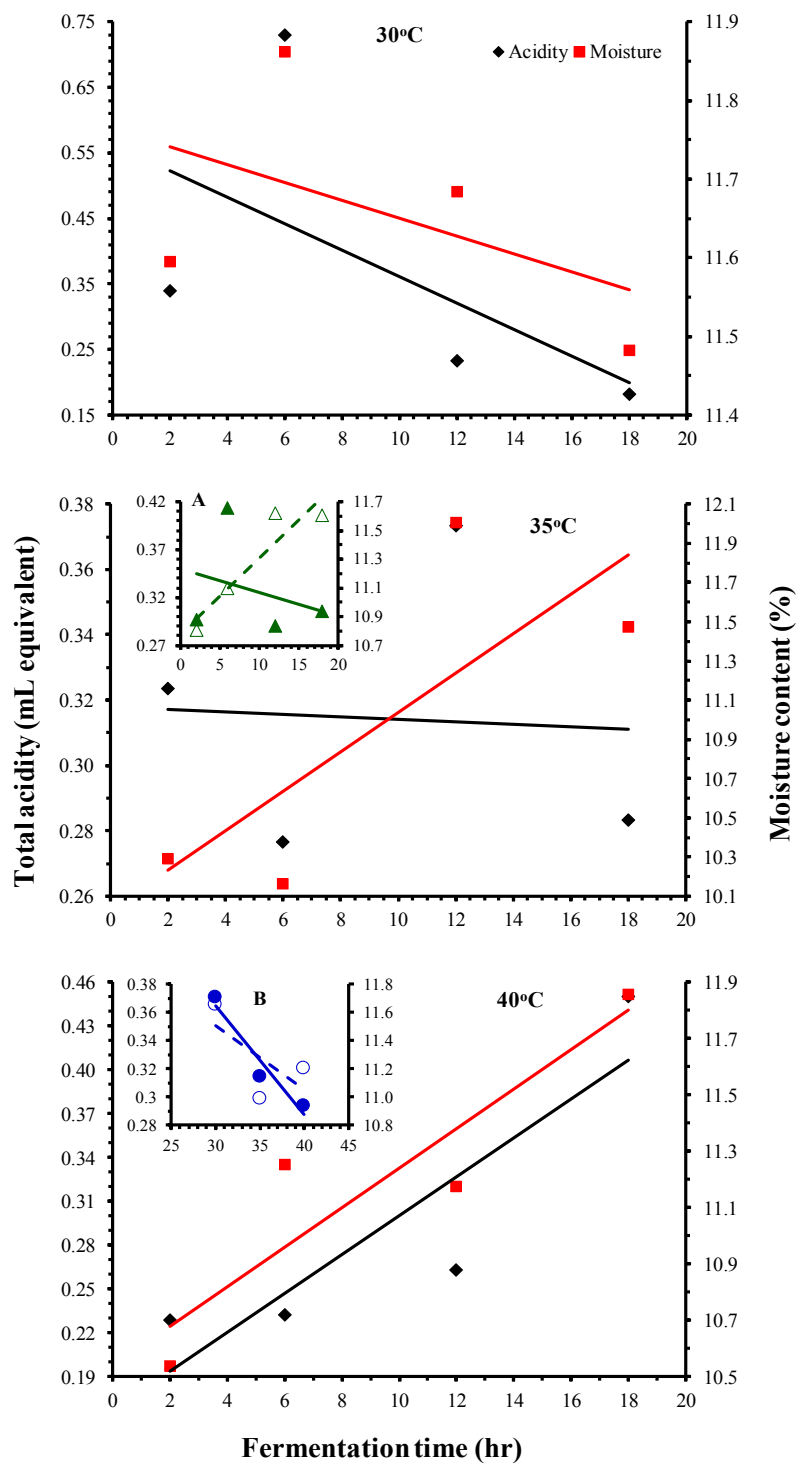

Figure 1. Effects of fermentation conditions on the total acidity and moisture of the coffee. Lines are indicative trends only.

\section{Conclusion}

Ohmic fermentation technology has been demonstrated to be useful for coffee processing. The technology produced a much lower total acidity fermented coffee. The temperature and time of the ohmic fermentation can reduce the coffee acidity from $1.87 \%$ (original fermentation) to $0.18 \%$ (ohmic fermentation) significantly.

\section{Acknowledgement}

The author would like to thank DRPM Dikti the Ministry for Research and Technology who have assisted with the research.

\section{References}

Alam, S. (2006). Coffee Development Feasibility as 
Commodity in South Sulawesi (In Bahasa). Indonesia: Agriculture Faculty, Hasanuddin University.

Association of Official Analytical Chemists (AOAC). (1995). Official methods of analysis of the association of official analytical chemists. Arlington: AOAC.

Avallone, S., Brillouet, J.M., Guyot, B., Olguin, E. and Gulraud, J.P. (2002). Involvement of pectolytic microorganisms in coffee fermentation. International Journal of Food Science and Technology, 37, 191199.

Budryn, G., Nebesny, E., Kula, J., Majda, T. and Kryslak, W. (2011). HS-SPMJME/GC/MS profiles of convectively and microwave roasted Ivory Coast Robusta Coffee brews. Czech Journal of Food Science, 29(2), 151-160

Bytof, G., Knopp, S.E., Schieberle, P., Teutsch, L. and Selmar, D. (2005). Influence of processing on the generation of gamma-aminobutyric acid in green coffee beans. European Food Research and Technology, 220 (3-4), 245-250.

Chang Lin, C. (2010). Approach of improving coffee industry in Taiwan-promote quality of coffee bean by fermentation. The Journal of International Management Studies, 5.

FAO, 2015. Worldwide Production of Coffee Beans. Retreived on March 20, 2016 from FAO website: http://faostat3.fao.org/faostat- gateway/go/to/home/ E

Farah, A., Monteiro, M.C., Calado, F., Franca, A.S. and Trugo, L.C. (2006). Correlation between cup quality and chemical attributes of Brazilian coffee. Food Chemistry, 98, 373-380

Hanifah, N. and Desy, K., 2013. Effect of alkali solution and yeast against total acids, caffeine, and fat coffee fermentation (In Bahasa). Journal Teknologi Kimia dan Industry, 2(2), 162-168

ICO. (2015). Coffee Statistics International Coffee Organization. Trade Statistics of Total Production of Exporting Countries. Retrieved from: http:// www.ico.org/International Coffee Organization.

Ismayadi, C. 1998. Arabica coffee quality improvement efforts specialty high plains Gayo, Aceh (In Bahasa). Warta Pusat Penelitian Kopi dan Kakao, 14, 45-53.

Jackels, S.C. and Jackels, C.F. (2005), Characterization of the coffee mucilage fermentation process using chemical indicators: a field study in Nicaragua. Journal of Food Science, 70, C321-C325.

Jayus, Giyarto, Nurhayati. and Aan. 2011. The role of microflora in fermentation Wet Robusta Coffee Bean (Coffea canepora) (In Bahasa). Jember: Fakultas Teknologi Pertanian, Universitas Jember

Laode, A., Mariati, B., Yusri, M.Z. and Nirwana, A.C. (2006). Analysis on agricultural enterprise of organic and inorganic coffee in South Sulawesi.

Misnawi. and Sulistyowati. (2006). Indonesian coffee quality and competitiveness improvement opportunities (In Bahasa). Warta Pusat Penelitian Kopi dan Kakao Indonesia, 22, 127-132.

Mulato, S. (2001). Caffeine dissolution Robusta bean with Fixed column using Liquid Solvents (In Bahasa). Jakarta: Pelita Perkebunan

Puslitkoka Indonesia. (2011). A cup of coffee dispensing. Tradition. $1^{\text {st }}$ ed.

Pimenta, T.V., Pereira, R.G.F., Correa, J.L.G. and Silva, J.R. (2009). Roasting processing of dry coffee cherry: Influence of grain shape and temperature on physical chemical and sensorial grain properties. B.CEPPA Curitiba, 27(1), 97-106.

Redgwel, R. and Fischer, M. (2006). Coffee carbohydrates. Brazilian Journal of Plant Physiology, 18(1), 165-174

Taba, J. (2012). Coffee taste analysis of an espresso coffee using nuclear magnetic spectroscopy. Eindhoven, Holland: Ostrobothnia University of Applied Science, BSc. Thesis

Wang, N. (2012). Physicochemical changes of coffee beans during roasting. Ontario, Canada: University of Guelph, MSc. Thesis.

Wirabuana, D.K.K. (2003). The content of caffeine and polyphenols in coffee beans are Arabica (Coffea Arabica, L) in Enrekang (In Bahasa). Jurnal Alam dan Lingkungan 4(7) 2013. ISSN 2086.4604. 